\title{
Analysis of Internal Factors of the Swing States in the International Climate Change Negotiations: A Case Study of Poland in COP24
}

\author{
Majid Asadnabizadeh \\ Department of International Relations, Maria Curie-Skłodowska University, Lublin, Poland \\ Email: Majid.asadnabizade@yahoo.com
}

How to cite this paper: Asadnabizadeh, M. (2019) Analysis of Internal Factors of the Swing States in the International Climate Change Negotiations: A Case Study of Poland in COP24. American Journal of Climate Change, 8, 263-283.

https://doi.org/10.4236/ajcc.2019.82015

Received: March 28, 2019

Accepted: June 3, 2019

Published: June 6, 2019

Copyright () 2019 by author(s) and Scientific Research Publishing Inc. This work is licensed under the Creative Commons Attribution-NonCommercial International License (CC BY-NC 4.0).

http://creativecommons.org/licenses/by-nc/4.0/

\begin{abstract}
The objective of this paper is to generate insights into the role of states in the international climate change negotiations and implementation of climatic agreements by considering their internal factors based on recent climate change conferences. In this paper, the notion of swing states and recognition are used to determine influential drivers in Poland as it played out a different role over climate change agreements recently. The case study of Poland demonstrates how international obligations, domestic factors, and formation of policy can change the function of a state at international negotiations such as Katowice Conference of Parties_COP24-in December 2018. This research through reference to qualitative indices elaborates how the position of Poland in the recent international climate change negotiations-Cop24-has been shaped? In the conference of parties 24, Poland approached other developed countries that shared its tendency for cutting emission, delivered signals of political attention and solidarity in finding a common landing ground. In sum, the framework of analysis and our results revealed the importance of economic interest, domestic political interests, and passive public awareness to set up to the task in the international agreements such as Katowice negotiation by Poland. To be clearer, the most influential factor of Poland in affecting its role in international climatic negotiations is internal political and economic interests.
\end{abstract}

\section{Keywords}

Swing States, Climate Change Negotiations, Poland, COP24

\section{Introduction}

In 1992, during the Rio Summit, 154 States, recognizing the existence of climate 
change resulting from human activity, decided to work together to limit global warming. This heralded the birth of the United Nations Framework Convention on Climate Change (UNFCCC) and its decision-making body, the Conference of Parties [1]. The COPs, which regularly convenes once a year for about two weeks, is charged with making decisions toward meeting the UNFCCC's goals and overseeing the implementation of its decisions. It is during COPs that states formulate, negotiate, publicize their intentions, policies and collective decisions regarding climate change and creating alliances or blocks [2]. Alliances are more or less formalized groupings of convenience formed to achieve collective change or to defend a status quo. The identity of formal negotiating groups derives mainly from regional, social, economic, political or even ideological characteristics [3]. According to Porter and Welsh brown in the negotiations on any given environmental regime on the global political agenda, a state actor may play one of four possible roles: lead the state, supporting state, swing state and veto state. A lead state has a strong commitment to effective international action on the issues. A supportive state may be either behind stronger action from the beginning or initially uncommitted. A swing state demands significant concessions to its interest as a price for going along with an agreement for which it lacks enthusiasm. A veto state opposes an effective environmental regime through intransigence in the negotiations or by violating its spirit in implementing [4]. USA and China, as an example, were lead states during Cop21 in Paris in 2015. Together, the US and China represent about 40 percent of global emissions. A partnership between China and the US paved the way for the Paris agreement under President Obama. Parker and Karlsson explained that Obama declared that the US was the key leader in getting the Paris Agreement done and it would not have happened without American leadership [5]. In a few cases, a lead role may give way to veto role due to its domestic and international policies. In the recent international climate change conference of parties in Katowice, of Poland countries such as: United States worked with Russia, Saudi Arabia, and Kuwait and blocked nearly 200 nations involved in the UN Framework Convention on Climate Change from "welcoming" a UN report in October saying that "unprecedented" action is required to keep warming to 1.5 degrees Celsius and stave off worldwide hardship [6].

Thus, numerous past investigations, and scholarly have considered the role of the lead and veto states as a unitary or actors in international climate change negotiations for understanding Global climate change leadership and the individual leadership roles of Specific states in shaping negotiation outcome. In other words, few examine the role of swing states. In order to address this gap and problem in the scientific literature, the aim of this paper is to contribute to this understanding by describing, explain and analyze the function of swing states via considering the position of Poland as an important case study in COP24 negotiations.

The Poland case as a coal-dominated country is globally illustrative. "Climate 
change regional review", declares (303) Poland heavily relies on coal, more than other countries in Europe. More than $90 \%$ of electricity is produced from coal. On the other hand, energy production from coal is the main source of its $\mathrm{CO}_{2}$ emissions [7]. Poland signed the United Nations Framework Convention on Climate Change Convention in 1992 and ratified it in 1994. The Kyoto Protocol was signed by Poland in1998 and ratified in 2002 so that for a while more emphasis was placed on this issue. At those times, Poland had played the role of opposing more vigorous moves in the inter-EU debates on climate policy. Poland is therefore not a frontrunner in arguing for climate change mitigation. Neither was it a frontrunner in other internationally recognized environmental issues, such as ozone layer, acid rain, air pollution [8]. Before the COP24, Poland had passed a bill in 2018 specifically for the UN summit which, according to environmental groups, will exclude members of civil society from the Paris Agreement process and endanger activists who have been threatened in their home countries. Poland's President Andrzej Duda signed the bill at the end of January, but it had gone widely unnoticed by the international community [9].

Hence, the main question is how the position of Poland-like a swing state-in the recent international climate change negotiations-Cop24-has been shaped? I argue that numerous factors recognized within the dated literature merely influence the external factors such as Poland energy policy and its relations with the EU. Therefore, based on qualitative methodology and analysis of factor technique domestic political and economic factors alongside the passive public awareness are significant determinants of Poland as swing state to shape its climate change agenda, policy and implement regulatory climate change negotiations. In what follows, so as to address this problem I first explain Katowice negotiations and evaluate the Poland position at Katowice conference as Preparations for the implementation of the Paris Agreement. Then in the final section discuss what factors determine a state's negotiating position-Poland-in COP24.

\section{Understanding Katowice Climate Change Negotiations}

Priestley highlighted that the 24 sessions of the Conference of the Parties to the UN Framework Convention on Climate Change (UNFCCC) (COP24) was held on 2-14 December 2018 in Katowice, Poland. The key objective for COP24 was to agree and adopt a package of decisions to ensure the full implementation of the Paris Agreement (agreed at COP21). Formally as the Paris Agreement Work Program (PAWP), or more informally as the Paris "rulebook" [10]. The COP24 in Katowice, Poland, was particularly crucial because 2018 was the deadline that the signatories of the Paris Agreement agreed upon in order to adopt a work program for the implementation of the Paris Commitments. The discussion was based on scientific evidence gathered over the years and assessed by experts [11]. Thus, clearly, 24 years after the first COP, Katowice negotiations warned that the international community only has a 12-year window to drastically reduce greenhouse gas emissions due to below-mentioned facts. 


\subsection{IPCC Report}

According to new research conducted by IPCC stated that the Special Report on Global Warming of $1.5^{\circ} \mathrm{C}$ was approved by the IPCC in October 2018 in Incheon, Republic of Korea. It would be a key scientific input into the Katowice Climate Change Conference in Poland in December when governments review the Paris Agreement to tackle climate change. The report highlights a number of climate change impacts that could be avoided by limiting global warming to $1.5^{\circ} \mathrm{C}$ compared to $2^{\circ} \mathrm{C}$, or more. For instance, by 2100 , global sea level rise would be $10 \mathrm{~cm}$ lower with global warming of $1.5^{\circ} \mathrm{C}$ compared with $2^{\circ} \mathrm{C}$. The likelihood of the Arctic Ocean free of sea ice in summer would be once per century with global warming of $1.5^{\circ} \mathrm{C}$, compared with at least once per decade with $2^{\circ} \mathrm{C}$. Coral reefs would decline by $70-90$ percent with global warming of $1.5^{\circ} \mathrm{C}$, whereas virtually all (>99 percent) would be lost with $2^{\circ} \mathrm{C}$. The report finds that limiting global warming to $1.5^{\circ} \mathrm{C}$ would require "rapid and far-reaching" transitions in land, energy, industry, buildings, transport, and cities. As Global net human-caused emissions of carbon dioxide $\left(\mathrm{CO}_{2}\right)$ would need to fall by about 45 percent from 2010 levels by 2030, reaching "net zero" around 2050. This means that any remaining emissions would need to be balanced by removing $\mathrm{CO}_{2}$ from the air [12]

\subsection{Emissions Gap Report}

The annual UN Environment Emissions Gap Report presents an assessment of current national mitigation efforts and the ambitions countries have presented in their Nationally Determined Contributions, which form the foundation of the Paris Agreement [13]. A new report (2018) released by the United Nations Environment Program (UNEP) shows that global carbon dioxide $\left(\mathrm{CO}_{2}\right)$ emissions rose again during 2017 after a three year hiatus, highlighting the imperative for countries to deliver on the historic Paris Agreement to keep global warming to below $2^{\circ} \mathrm{C}$ above pre-industrial levels (Figure 1). The report comes just days before the key UN climate change conference known as COP24, taking place in Katowice, Poland, with the agency urging nations to triple their efforts to curb harmful emissions.

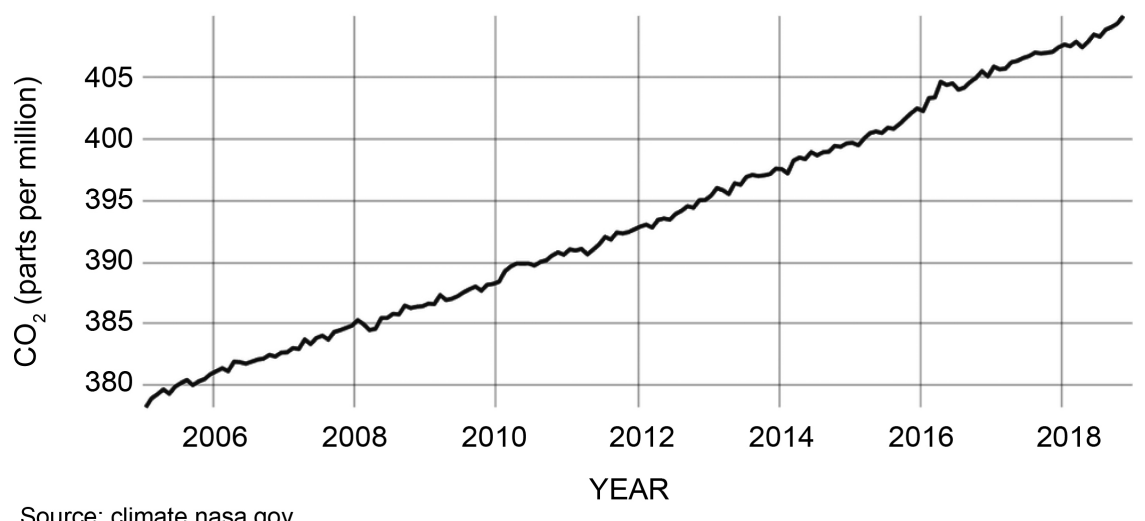

Source: climate nasa.gov

Figure 1. Emission of $\mathrm{CO}_{2}$, Adopted from: NOAA, 2019. 
This ninth UNEP emissions report has been prepared by an international team of leading scientists, assessing all available information. Therefore, the 2018 Global Emissions Report adds yet another building block of scientific evidence to inform decision-making at the UN climate change conference-the COP24 in Poland [14].

\subsection{Bulletin on Greenhouse Gas Concentrations}

Levels of heat-trapping greenhouse gases in the atmosphere have reached another new record high, according to the World Meteorological Organization (WMO). There is no sign of a reversal in this trend, which is driving long-term climate change, sea level rise, ocean acidification and more extreme weather [15]. Fourteenth WMO Greenhouse Gas Bulletin reports atmospheric abundances and rates of change of the most important Long-Lived GHGs (LLGHGs)- $\mathrm{CO}_{2}$ (Carbon dioxide), $\mathrm{CH}_{4}$ (Methane) and $\mathrm{N}_{2} \mathrm{O}$ (Nitrous oxide) - and provides a summary of the contributions of other gases. These three, together with CFC-12 and CFC-11, account for approximately $96 \%$ (4) of radiative forcing due to LLGHGs [16]. For $\mathrm{CH}_{4}$, the increase from 2016 to 2017 was lower than that observed from 2015 to 2016 but practically equal to the average over the last decade. For $\mathrm{N}_{2} \mathrm{O}$, the increase from 2016 to 2017 was higher than that observed from 2015 to 2016 and practically equal to the average growth rate over the past 10 years (Figure 2) (Ibid, 2018). Therefore, the urgency of activities to reduce greenhouse gas emissions requires more instruments at the national and sub-national level to back partners in taking compelling and proficient activities and following international negotiations in Poland.

\subsection{Ozone Depletion Assessment}

This assessment is required by the Montreal Protocol on Substances that Deplete the Ozone Layer and is completed under the auspices of the United Nations Environment Program and the World Meteorological Organization [18].

The press release (2018) mentioned that the 2018 Assessment is the latest in a series of assessments prepared by the world's leading experts in the atmospheric sciences and under the auspices of the Montreal Protocol in coordination with the World Meteorological Organization (WMO) and the United Nations Environment program (UN Environment) [19]. Scientific Assessment of Ozone
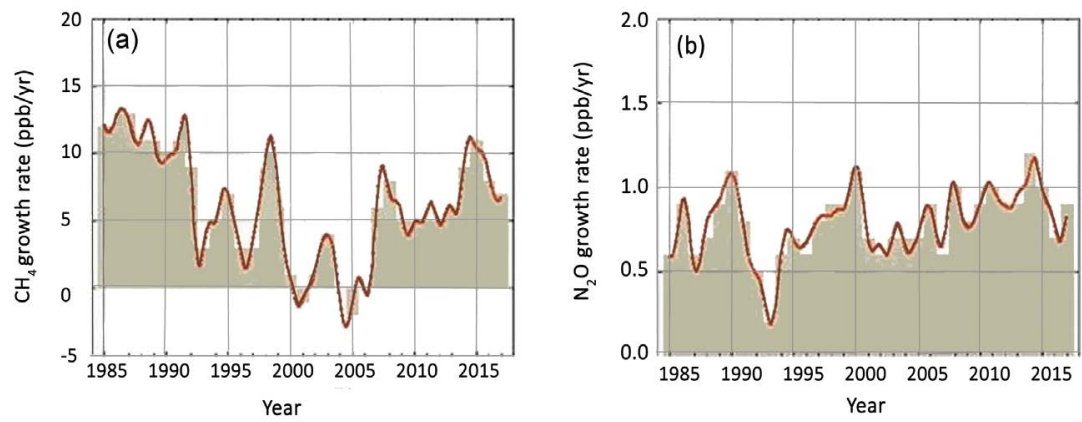

Figure 2. The trajectory of $\mathrm{CH}_{4}$ and $\mathrm{N}_{2} \mathrm{O}$. Adopted from: [17] WDCGG, 2018. 
Depletion (2018) reveals that actions taken under the Montreal Protocol have led to decreases in the atmospheric abundance of controlled ozone-depleting substances (ODSs) and the start of the recovery of stratospheric ozone [20]. Purohit et al. noticed that the Protocol and all amendments except its newest, the Kigali Amendment, have been ratified by 197 parties. The high Global Warming Potentials (GWP) of hydro fluorocarbons HFCs replacing ODSs is a climate concern and the reason behind the Kigali Amendment of the Montreal Protocol adopted during the 28th Meeting of the Parties 8-14 October 2016 in Kigali, Rwanda to phase-down the use of HFCs globally by 2050 [21]. Also at Katowice, the Kigali Cooling Efficiency Program (K-CEP) - Refrigeration, air conditioning, and other forms of cooling are essential to human health and prosperity and are becoming more important as the world urbanizes, economies grow, and the planet warms. But cooling is also contributing to a warming planet, as it relies heavily on climate polluting chemicals known as hydro fluorocarbons (HFCs) and consumes massive amounts of electricity-presented a new Cooling as a Service Initiative with the Basel Agency for Sustainable Energy (BASE) [22]. Subsequently, this evidence illustrated that COP24 can be a culminating time for nations and leaders to focus on important issues such as HFC since its fast-growing source of GHG. Moreover, developed countries will provide finance and technology to developing countries to assist in climate change adaptation and mitigation efforts in this case.

\section{Poland Position in COP24 as a Swing State}

Poland contributes to the activities towards climate change negotiations and mitigation undertaken by the international community-as a signatory to the United Nations Framework Convention on Climate Change since 1994 and to the Kyoto Protocol-since 2002 [23]. Poland ratified the Kyoto Protocol in December 2002. Once the Protocol was ratified, EU member states and applicants began to develop National Allocation Plans (NAPs), or statements specifying how each country would allocate its emissions rights. Poland, with its significant emissions surplus, might have been expected to receive the European Commission's endorsement of its NAP quite easily. In fact, however, that was not the case: the Commission would not approve the Polish plan until the country cut its planned emissions allowances by $16.5 \%$, or 141.3 million tons of $\mathrm{CO}_{2}$, for the period between 2005 and 2007. The Polish government attempted to revise the plan but ran into significant opposition from Polish companies. Since Poland could not negotiate over the ruling of the European Commission, it sought to cut its allocations without hurting domestic industries [24].

Skoczkowski (2018) highlighted that, Poland has, as a signatory to the Kyoto Protocol since 2002, two legally binding obligations on the GHG reduction, namely, the first one stemming from the protocol to reduce its emissions by $6 \%$ in 2008-2012 in relation to 1998 as the base year, and the second one of reduction $20 \%$ in 2013-2020 as the EU Member State (MS). Despite successes in 
meeting these GHG reduction goals, Poland's climate policy has been heavily criticized by environmentalists who blame insufficient measures undertaken to curb GHG emission caused by extensive coal use. In the opinion of the European Environmental Agency (EEA), Poland remains one of the most material- and energy-consuming economies of the EU in terms of efficiency. As well, Poland is known as a major opponent to the EU climate policy. Poland has long been a problem child of the EU when it comes to implementing harsher climate targets. In 2012 it vetoed the EU's low carbon roadmap and again opposed the 2030 climate targets of 2014 [25].

The European Union officially ratified the Paris climate agreement, along with several member nations. Among them was a most unlikely signatory: Poland, whose reliance on coal had previously threatened the deal. Polish energy security is based almost entirely on coal. In 2018, more than 80 percent of the country's electricity was generated in coal-fired power plants (Figure 3) [26]. Anderson emphasized that the notion of Poland as a country that "stands on coal" was enabled and fuelled by abundant resources of both hard coal and lignite. This indigenous coal played a key role in rebuilding the country after the Second World War and during the cold war, with the subsequent communist period overseeing a peak in production during the 1980s. Following the collapse of communism, the energy strategy of the new and democratic government viewed Poland's coal "monoculture" as a challenge to the development of a progressive society. "Black gold" provided $97 \%$ of electricity generated in 1990, a legacy successive government have struggled to escape. Although Poland meets the Kyoto commitments, the bulk of its emission reductions were a consequence of the prolonged recession accompanying the country's economic transition [27]. Accurately, at the climate summit in Paris 2015, Poland blocked the EU's efforts to include the word "decarbonisation" in the text, instead of pushing for the less

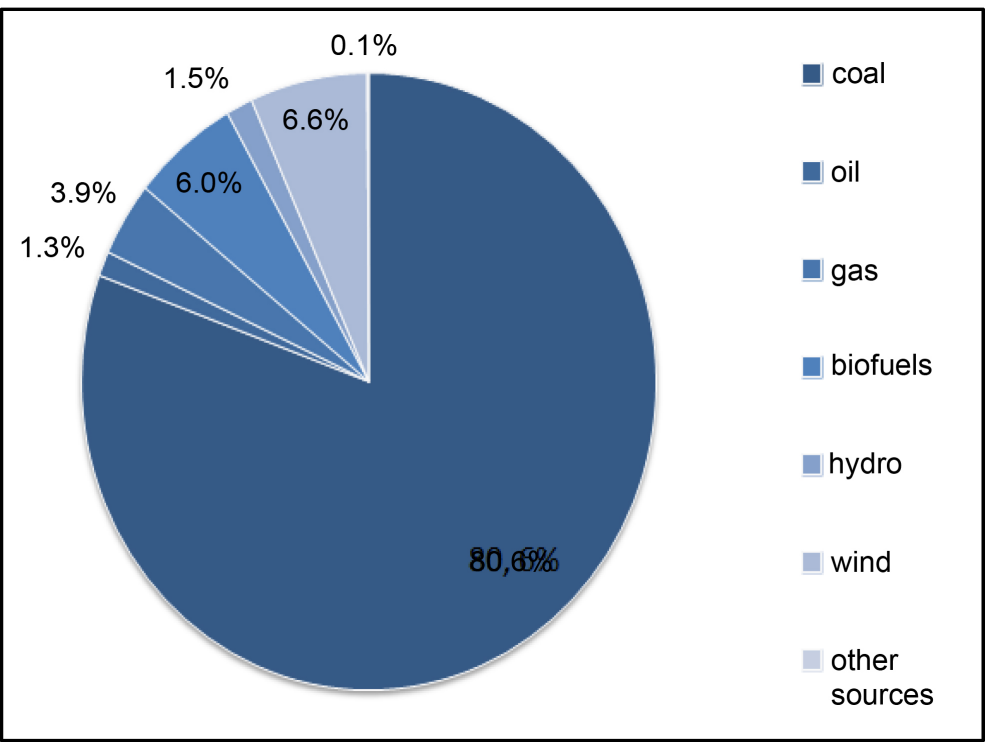

Figure 3. Production of electricity. Adopted from: [29]. 
explicit "carbon neutrality". At COP23 in Bonn, the country continued to oppose the concerted effort of the EU to ratify the Doha Amendment to the Kyoto Protocol, which enforces pre-2020 climate mitigation efforts [28].

Poland is still regarded as an economy undergoing a transformation, but thanks to intensive efforts it has significantly reduced emissions of harmful pollutants and at the same time strengthened its international position in the context of international climate negotiations and actions [30]. Don Lehr indicated that, at the Pre-COP24 meeting in Kraków on 23-24 October, Kurtyka-the Secretary of State in Poland s Ministry of Environment-called for more climate ambition and for completion of the PAWP implementation rules, noting that the recently-released IPCC Special Report on Global Warming of $1.5^{\circ} \mathrm{C}$ is aimed to be a catalyst for scaled-up investment in green technologies, and for a rapid phase-out of coal. Climate change is a global challenge, said Kurtyka, and there is no room for arbitrarily chosen local or national policies. The Polish Presidency has defined the three key messages which it considers most important in the Polish context to COP24. They are summarized under "Man, Technology, Nature" standing for Just Transition, electromobility, and climate neutrality. These are important topics for the Polish energy and climate debate (especially electromobility is a potential driver of economic development) and it is a positive sign that the Poland and government are addressing climate change and negotiations differently [31]. Therefore, this climate conference-COP24-came at a critical moment for setting the Paris Agreement in motion. Negotiators needed to finalize the rules for the implementation of the Paris Agreement, send a collective signal on enhancing national commitments under Paris (NDCs) by 2020 , and deliver progress on the issues around climate finance. All of these are essential to effectively pursuing the Paris Agreement vision built around fulfilling and regularly strengthening countries commitments. As the birthplace of NDCs, Poland had an opportunity at Katowice to build a legacy by putting the implementation and enhancement of ambitious NDCs firmly on track [32].

The author argued that Poland has been attempting to reveal a new perspective and sustainable methods for taking care of the international climate change negotiations and combating climate change threats. This is the third time-COP24-that Poland is the host of most important climate change negotiations. To be more exact, Poland demonstrated its position in recent cops and negotiations as a veto state, but in COP24 they changed functions towards the progressive state. They showed that Poland wants to continue its new roles and suggest tougher policies and recommendations on how we can deal with climatic matters by following previously agreed rules. Hence, Poland has to be considered as a swing state in COP24. Richard Fontaine and Daniel Kliman in an interview highlighted that, Global swing states are nations that possess large and growing economies, occupy central positions in a region or stand at the hinge of multiple regions, and embrace democratic government at home. Increasingly active at the regional and global level, they desire changes to the existing interna- 
tional order but do not seek to scrap the interlocking web of global institutions, rules, and relationships that have fostered peace, prosperity, and freedom for the past six decades [33]. To give more concrete reasons that Poland is playing the role of a swing state in COP24 the rest of this paper would invest in main factors which derive from government decisions.

\section{Analysis of Factors that Highlights the Position of Poland in COP24}

Based on authors assessments understanding the reasons for the new role of Poland within climate change negotiations-COP24-can shed light on internal factors that contribute to differences across other countries functions. Several factors specifically explain the Poland position as a swing state that is observed before and within the process of Katowice negotiations. However, evidence suggests that political and economic dynamics with public awareness are significant in shaping a new image of Poland as a swing nation (Figure 4). Key factors which shaped by governmental decisions and based on importance would be analyzed by the author in this research.

\subsection{Domestic Political Drivers}

Poland is the most hardline climate policy opponent in Central and Eastern

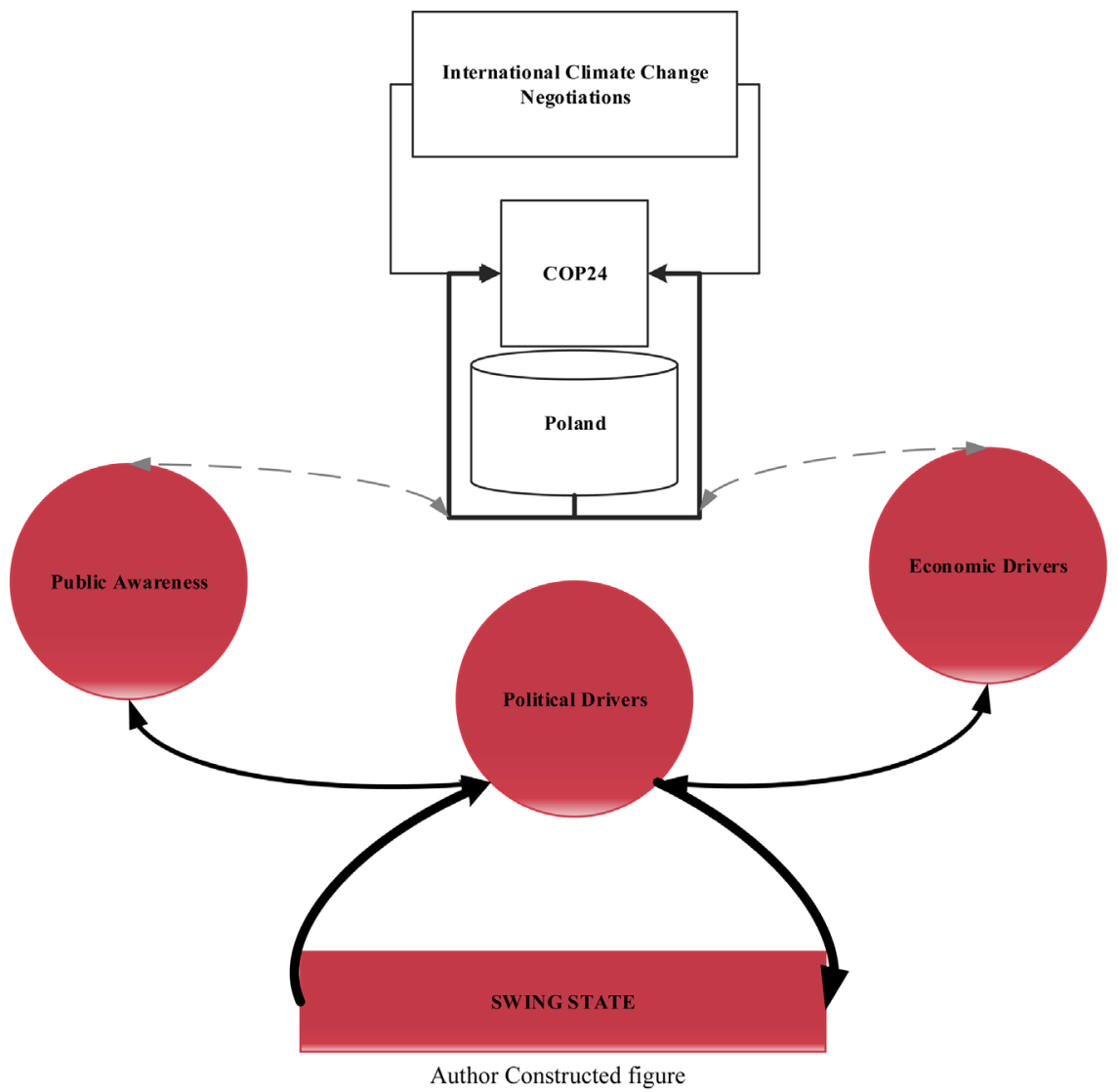

Figure 4. The position of Poland in COP24. 
Europe (CEE). The main reason for this stance is the historically important role of the coal industry, which still provides close to 100,000 jobs and is seen as the answer to energy security problems resulting from dependence on Russian gas and oil imports. As the major coal companies are all partially or fully state-owned, the government and policies also have a direct impact and financial stake in the success of the economy and the coal industry [34]. Lachapelle claimed that, not surprisingly, the two key factors, which appear to influence countries' commitment to achieving climate policies, are fuel dependency and economic crisis. The countries with substantial exports of mineral fuels are less likely to implement any type of climate policy [35]. In 2015 Law and Justice (PIS), won the first majoritarian single-party cabinet in the post-communist era in Poland. Polish President Andrzej Duda sent a strong signal that business, as usual, is over when it comes to his country's climate policy-vetoing an extension of the 1997 Kyoto climate protocol as his right-wing party took control of the EU's sixth largest country [36]. Duda slammed the Polish government and incumbent president Bronislaw Komorowski for accepting a package the main objective of which is to cut greenhouse gases emission in the EU by $40 \%$ by 2030 . The move threatens Poland's coal-based energy security, Duda argued [37]. Recently, the Polish government shows new signals and its Presidency played differently and managed to get the result at the heart of COP24: agreement on the all-important "Rule Book" that will allow governments to move ahead with implementing the Paris Agreement [38]. Hence, to support this view the author has discovered influential factors which would be outlined in the following sections.

\subsubsection{First Signal-Ratification of Doha Amendment}

The Doha conference, which marks the end of the first Kyoto commitment period, was held on 26 November 2012-8 December 2012. Only 4 countries, Australia, Norway, Switzerland, and Ukraine agreed with the EU on emission reductions for Kyoto continuation period until 2020, when the new agreement, which is binding for all countries is meant to enter into force. In Doha it was decided that the emission allowances that had not been used during the first commitment period could be transferred to the second period, albeit with some restrictions with regard to purchases: by purchasing these types of allowances a country cannot set off more than $2 \%$ of its own reduction targets. Throughout the Doha conference, Poland was considered the problem child. This also becomes evident in an internal memorandum of European People's Party group (EPP): on the KP2 point there has been a moment of big tension when Poland blocked on the credentials and did not want EU to sign the KP. After some discussions, Poland moved and the EU and also the other 4 missing countries signed [39].

At the United Nations in New York on September, Poland deputy environment Minister Micah Kurtyka who served as a chair of the United Nations climate change meeting in Katowice told: "we are ratifying the Doha amendment in a symbolic way in, together with other countries" [40]. Following that, based on Reuter's reports, Poland became on 2018 the final EU country to enact a bill 
ratifying the global agreement intended to provide a legal framework for reducing carbon emissions, which paves the way for the entire European Union to accept the accord as a bloc. Polish President Andrzej Duda's signature on a bill ratifying the so-called Doha amendment to the Kyoto protocol was the last step needed for all $28 \mathrm{EU}$ members to have separately enacted it. The EU cannot enact it as a whole until all members have done so. The Doha amendment does not come into effect unless 144 countries ratify it, which 111 states had done as of March 29, according to the United Nations. The president's office also said in a statement that Poland plans to submit an extra declaration, in which it will secure the right to decide on the energy sources on which it wants to rely [41].

\subsubsection{Second Signal-Polish-Drafted Initiative for Jungle and Climate}

Warsaw has repeatedly said it needs time to reduce its reliance on coal and has meanwhile launched campaigns to promote the use of forests to capture carbon, as well as electric vehicles to reduce diesel pollution. Environment Minister Henryk Kowalczyk noted that the U.N. Intergovernmental Panel on Climate Change (IPCC) recently determined that it was not possible to limit global warming without curbing carbon emissions. The IPCC report said that to limit temperature rise to $1.5 \mathrm{C}$, an increase of up to 9.5 million square kilometers of forests would be needed by 2050, compared to 2010 levels, among other measures. One third of Poland's land mass is covered by trees and the country is planting more. Ahead of the global climate talks Warsaw has promoted so called Carbon Forest Projects, which are expected to absorb about 1 million tons of $\mathrm{CO}_{2}$ [Ibid]. During the COP24, there were special thematic days dedicated to different subjects at the summit, including Electro mobility Day (4 December) and Forest Day (7 December). The Ministerial Katowice Declaration "Forests for Climate"1 elaborated by the Polish Presidency of COP-24 was launched on 12 December. Worth noticing is that the ability of forests to absorb $\mathrm{CO}_{2}$ can actually be increased by planting appropriate tree species [42]. Ministerial declaration report notes that:

1) The important role of forests as sinks and reservoirs of greenhouse gases, in mitigating climate change, and simultaneously recognizing the need for reducing emissions from deforestation and forest degradation, and forest conservation, sustainable management of forests.

2) Recognizing that climate change is affecting forests, under certain circumstances, as a result of natural disasters, leading to increased emissions, affecting the carbon storage capacity of forests and underlining the need to increase the capacity of forests to adapt to climate change.

\footnotetext{
${ }^{1}$ List of parties supporting the "Forests for Climate" Declaration: Albania. Andorra. Antigua and Barbuda. Argentina. Australia. Austria. Bahrain. Belgium. Bulgaria. Cambodia. Canada. Central African Republic. Chile. China. Croatia. Cyprus. Czech Republic. Democratic People's Republic of Korea. Denmark. Estonia. Ethiopia. Fiji. Finland. France. Georgia. Germany. Greece. Hungary. Indonesia. Ireland. Italy. Japan. Kuwait. Lao People's Democratic Republic. Latvia. Lithuania. Luxembourg. Malta. Mexico. Monaco. Morocco. Netherlands. New Zealand. Norway. Paraguay. Poland. Portugal. Republic of Korea. Romania. Russian Federation.
} 
3) Sharing the UN Strategic Plan for Forests' vision of a world in which all types of forests and trees outside forests are sustainably managed, contribute to sustainable development and provide economic, social, environmental and cultural benefits for present and future generations [43].

\subsubsection{Third Signal-A Joint Initiative of Poland and Great Britain for Electromobility Declaration}

Secretary of State at the Ministry of the Environment, President of COP24 Michał Kurtyka presented a new initiative for the development of electro mobility and zero emission transport "Driving Change Together Partnership". The Polish COP24 Presidency proposed establishing e-mobility as one of the main topics of COP24 and to launch a Partnership in this area. "We want these actions to become an impulse towards ensuring universal opportunities to live in clean, environmentally friendly cities" he stressed [44]. The Katowice Partnership for Electromobility ${ }^{2}$ is a joint initiative of Poland and Great Britain government aimed at promoting transport based on low and zero emission vehicles. Electromobility is an alternative to petrol-powered transport, demanding international cooperation and exchange of experience in order to make it possible to implement [45].

More specifically, the aim of the partnership is to bring together countries, regions, cities as well as institutions, non-governmental organizations, and companies working on developing electromobility. The way to accomplish this task is through international cooperation and exchanging experiences in this field. Of particular importance here will be the assistance provided for research and development in technologies related to electromobility; for the construction of infrastructure for electric vehicles; creating an incentive system for buyers of vehicles, setting targets related to electric fleets and to public procurements Moreover, the polish government believes that Electromobility could help the electricity sector in Poland. In the initial stage, the investment resulting from electric vehicles deployment will strengthen the transmission and distribution grids. Implementing electromobility meets a number of objectives of sustainable energy and environmental policies. It reduces dependence on imported oil, aids the modernization of the energy sector, stabilizes the energy system and improves air quality in cities [46].

\subsubsection{Fourth Signal-Polish-Drafted Solidarity and Just Transition Silesia Declaration}

At COP24, Andrzej Duda emphasized the importance of social consensus as a

\footnotetext{
${ }^{2}$ Signatories of the declaration "driving change together-katowice partnership for electromobility": Austria. Andorra. Belarus. Canada. Cyprus. China. Costa Rica. Czech Republic. Denmark. Egypt. Finland. France. Gabon. Georgia. Germany. Greece. Honduras. Hungary. Iceland. Indonesia. Ireland. Japan. Korea, Republic of. Latvia. Lithuania. Mali. Malta. Mexico. Monaco. New Zealand. Norway. Palestine, State of. Poland. Portugal. San Marino. Slovakia. Slovenia. Spain. Sweden. Saudi Arabia. Serbia. Sierra Leone. Singapore. Slovakia. Slovenia. South Sudan. Spain. Sri Lanka. St. Lucia. State of Palestine. Sudan. Sweden. Switzerland. Thailand. The Former Yugoslav Republic of Macedonia. Ukraine. United Kingdom of Great Britain and Northern Ireland. Viet Nam. Ukraine. United Kingdom. Togo.
} 
condition for the success of environmental policies and presented the Silesia Solidarity and Just Transition Declaration to the Heads of States and Governments meeting. Drafted by Poland itself, this declaration recognizes the challenges for cities, sectors and local authorities that are dependent on fossil fuels and calls on governments to ensure a decent future for workers and communities affected by the transition to low carbon emissions-by protecting their rights and well-being. The new declaration was already signed by about 49 countries $^{3}$. It is also supported by organizations such as Amnesty International who consider that "it is vital that as governments transition our economies away from fossil fuels, they account for the human rights impacts on everybody" [47]. The signatories of declaration confirmed that social acceptance for change is of key importance for the successful building of a low-emission economy. This is why in the first place it is necessary to ensure the social safety of employees whose jobs will be liquidated or changed. The signatories acknowledged that special need of developing countries particularly those vulnerable to climate change, where lack of social safeguards seriously hinder a just transition [48].

Thus, the adoption of the Declaration on Just Transition at the Katowice Summit will give this issue additional political support. This will be another step towards mainstreaming this issue into global climate policy. The fact of signing this declaration in Poland brings significant benefits. This is where the vital interests of governments, workers, and employers around the world will gain valuable support. This will help to build the image of Poland as a modern state, paying attention to the issues of climate change, social cohesion, working for the well-being of all citizens and promoting the values of solidarity at the international level and negotiations [49].

\subsection{Domestic Economic Drivers}

From the author point of view, Poland has to make serious efforts to consider, identify the best economic mechanisms for reducing emission, especially fossil fuel industries and be active in international climate change negotiations over COP24. The Katowice Climate Summit was a special opportunity to present in the global perspective the current economic signals and attempts in climate protection, in Poland, the European Union and in the conference. Thus, in this section of paper much more attention should be placed on, for instance, changes in some of the industrial districts, an adaption of renewables, and coal companies, which is probably are important to shaping economic policy in Poland.

\subsubsection{Economic Change of Industrial Regions}

Poland has almost 30 industrial districts that are well-known mainly for coal

${ }^{3}$ List of countries endorsing the solidarity and just transition silesia declaration: Albania. Austria. Belgium. Bulgaria. Canada. Czech Republic. Denmark. Estonia. Fiji. Finland. France. Gabonese Republic. Germany. Greece. Honduras. Iceland. Indonesia. Japan. Republic of Korea. Latvia. Lithuania. Luxembourg. Macedonia. Madagascar. Montenegro. Namibia. Nauru. Nepal. Netherlands. New Zealand. Nigeria. Norway. Peru. Poland. San Marino. Serbia. Slovak Republic. Slovenia. Spain. Palestine. Sweden. Switzerland. Thailand. Togo. Ireland. Uruguay. 
mining. Located in south-western Poland, Silesia is the country's most industrialized region and its capital Katowice is the host city of COP24. This is not an accidental choice. Poland has been trying to create a modern hard coal mining sector by implementing innovative coal technologies, such as coal gasification. Plans are also being developed for the alternative development of former mines, e.g., the project of creating a pumped-storage power plant at the liquidated Krupiński mine in Suszec. In other words, the Polish government is trying to create favorable conditions for the construction of a profitable, effective and modern hard coal mining sector, based on cooperation, knowledge, and innovation. Pure, innovative coal technologies. Śląskie Voivodship was also included in the EU initiative addressed to the coal regions in the transformation period (Coal Regions in Transition). Among the projects submitted by Poland, there are plans to create a pumped storage power plant in Suszec or a project for hydrogen cells prepared by Jastrzębska Spółka Węglowa [50].

\subsubsection{Role of Fossil Fuel Companies in Cop24}

The state-owned coking coal company, Jastrzebska Spólka Weglowa SA, is the first corporate sponsor of the conference, followed by its state-owned utility company PGE Polska Grupa Energetyczna SA, which burns more coal than any other power company in Europe, and the Katowice-based Tauron Polska Energia SA, which owns coal mines (Table 1) [51]. During COP24, JSW organizes expert panels at which it will present the company's environmental efforts. It will present solutions guaranteeing reduction of emissions and allowing for efficient use of the natural resources and by-products of the production process. SW is a leader in the economic usage of methane. The gas captured from the mine

Table 1. Main corporate sponsors of COP24.

\begin{tabular}{|c|c|c|c|}
\hline Company & description & $\begin{array}{c}\text { Climate-wrecking } \\
\text { activities }\end{array}$ & $\begin{array}{c}\text { Green washing } \\
\text { activities }\end{array}$ \\
\hline $\begin{array}{c}\text { Jastrzębska } \\
\text { Spółka Weglowa } \\
(J S W)\end{array}$ & $\begin{array}{l}\text { One of the largest } \\
\text { tar producers in the } \\
\text { European Union, it is } \\
\text { one of the leading } \\
\text { coal companies in } \\
\text { Poland. }\end{array}$ & $\begin{array}{l}\text { JSW is one of Poland's } \\
\text { leading coal } \\
\text { companies, with plans } \\
\text { to further expand their } \\
\text { operations. }\end{array}$ & $\begin{array}{l}\text { JSW is also providing } \\
\text { a hydrogen powered } \\
\text { bus to shuttle around } \\
\text { COP participants and } \\
\text { delegates. }\end{array}$ \\
\hline $\begin{array}{c}\text { Polska Grupa } \\
\text { Energetyczna } \\
(P G E)\end{array}$ & $\begin{array}{l}\text { Largest energy sector } \\
\text { company in Poland }\end{array}$ & $\begin{array}{l}\text { PGE has teamed up } \\
\text { with Polish coal players } \\
\text { to make sure its } \\
\text { polluting plants can } \\
\text { keep receiving state } \\
\text { subsidies. }\end{array}$ & $\begin{array}{l}\text { This company has } \\
\text { been taking part in } \\
\text { public debates in } \\
\text { Brussels claiming it } \\
\text { supports the talks on } \\
\text { de-carbonization and } \\
\text { is changing direction. }\end{array}$ \\
\hline $\begin{array}{c}\text { Tauron Polska } \\
\text { Energia S.A. }\end{array}$ & $\begin{array}{l}\text { Poland's second } \\
\text { biggest electricity } \\
\text { generator and } \\
\text { supplier }\end{array}$ & $\begin{array}{l}\text { Tauron only narrowly } \\
\text { missed out on being } \\
\text { among the ten most } \\
\text { polluting coal } \\
\text { companies in Europe }\end{array}$ & $\begin{array}{l}\text { Tauron launched a } \\
\text { network of electric } \\
\text { car-sharing vehicles } \\
\text { and green charging } \\
\text { stations. }\end{array}$ \\
\hline
\end{tabular}


methane drainage and ventilation air system not only reduces the risk of methane hazards in mines but also improves energy efficiency and reduces greenhouse gas emissions into the environment. At present, $60 \%$ of the captured gas is converted into energy. By 2030, the company intends to increase electricity production from methane fivefold-says Artur Dyczko-JSW's Vice-President for Strategy and Development-JSW is taking intensive actions to implement technology for separation of hydrogen from coke-oven gas. Separated and purified hydrogen can be used in hydrogen cells for environmentally-friendly and emission-free generation of electricity or environmentally-friendly public transport [52].

\subsubsection{Adaption of Renewables}

Around $80 \%$ of Poland's electricity is generated using coal, and the country relies heavily on the fuel for heating. At Bloomberg's NEF Future of Energy Summit in October 2018, Polish politician Piotr Naimski explained that the country would not be turning its back on coal, and instead planned to continue mining and burning the controversial fossil fuel. Poland has begun to adopt renewables, but slowly. Wind turbines are being built in the Baltic Sea, but there is effectively no solar power and little hydro. This is despite the cost of renewables plummeting around the world, and technologies becoming increasingly efficient and reliable [53]. More specifically, in mid-2018, the parliament adopted a broad act on amending the renewable energy sources (RES) and wind energy and wind energy related legislation (ACT) amid at unlocking the development of new RES projects in Poland. While the act does not change certain obstacles to onshore wind amendments in the wind energy investments act do enable the construction of on shore wind projects that have already been granted permits or are in the process of granting such a permit. The act also significantly reduces the real property tax burden for wind turbines to the level before the adoption of wind energy investment act [54]. Moreover, Poland's energy policy 2040 is the response of the ministry of energy to the challenges of the global macroeconomic and climate trends through the diversification of Poland's fuel mix and sustainable fuel management. Poland's energy policy also assumes commissioning the first nuclear power plant in 2033with construction of others to follow in the 2043 perspective. Poland overriding strategic goals are to ensure the security of supply, competitiveness and at the same time care for the natural environment [55].

\subsection{Passive Public Awareness}

In 2015, the Pew Research Center carried out a 40-country public opinion survey about climate change. Brazilians appeared most concerned about climate change, with $86 \%$ considering it a serious problem. The majority of Europeans are very concerned (a median of 54\%, the same as the global median). The least concern was expressed in China (18\%) and Poland (19\%). Regardless of the level of concern, a majority of respondents are in favor of their country limiting 
greenhouse gas emissions as part of an international agreement (a global median of $78 \%$, with $63 \%$ in Poland and $71 \%$ in China) [56]. Pew interviewed over 45,000 people in 40 countries, including EU members Germany, France, UK, Italy, Spain, and Poland.

For many of the survey's questions, the responses from Poland stood out compared to those from the western European nations. Poland was the only European country-apart from Russia-where the group of people who think global climate change "is a very serious problem" has shrunk. In 2010, 31 percent of those surveyed in Poland held that view, while in 2015, only 19 percent do. Russia had a similar decrease, from 43 to 33 percent. Three percent of Poles even said that climate change doesn't exist-in voluntary statements, which weren't prompted by a Pew question [57]. Poland's passive position in international climate change discussions and policies is reflected in public attitudes and in the frames used in national climate change discourse. It could be argued that Poles are aware of the climate change issue, but is it not a priority issue for them. Even awareness is mixed, with some contradictions. It is also variable and strongly dependent on media representations. Half of Poles consider climate change as a serious issue, while one third regard it as very serious. In comparison to previous instigations, Public Opinion Research Center in 2018 indicated that the vast majority of Poles perceive climate change as a threat, with more than half (54\%) believing that this is just one of many dangerous phenomena. Less than one-third (29\%) of respondents believe that climate change is one of the greatest threats to modern civilization [7]. Few Poles claim that climate change is not at all dangerous (3\%) or that such a phenomenon does not exist (1\%) In addition to that, In the lead-up to COP24, Polish civil society had issued calls for a comprehensive phase-out of coal; a just transition strategy that would be prepared in a broad social dialogue; support for renewable energy and energy democracy; measures for energy efficiency and the improvement of air quality, and an ambitious declaration on cuts in greenhouse gas emissions.

The Polish climate movement has gained strength in the past months and, in fact, didn't exist until recently. Attempts to create movements occurred at the time of the two previous Polish COPs (COP14, Poznan, 2008 and COP19, Warsaw, 2013) but disappeared thereafter. In July, the first Polish climate camp hosted more than 400 people (a large number for Poland) from a broad range of grassroots movements. Numerous Catholic climate initiatives have also arisen, a potentially important advance for climate change awareness in a society where the Catholic Church is dominant and influential. Polish civil society has appealed to Prime Minister Mateusz Morawiecki to ensure the success of COP24, and to include civil society as a strong partner in the COP24 process, as was promised at the COP24 presidency's briefings at the Bangkok negotiating sessions in September [31].

\section{Conclusion}

Since the international community seeks synchronized mitigation of anthropo- 
genic climate change, Poland will need to make its strong contribution. As a signatory of Kyoto agreement Poland is responsible for about $2 \%$ of global greenhouse gas emission amongst other countries. Undoubtedly, Poland has been started gradually to reduce its emission and decarbonize the energy sector. This country as one of the members of the EU has to follow the rules and laws in regard to climate change policy and mitigation, although political, economic and societal participation is needed so as to consider these policies within EU and international negotiations. In COP24 Poland tried to play a different role in contrast to previous negotiations. The position of Poland in COP19 in Warsaw by 2013 was neutral but in the recent international negotiations, it revealed both constructive and progressive image. The environment of COP24 was as hopeful as it was during the most important previous negotiations in Paris, and it was due to Poland new position on global climate change negotiations in terms of political, economic and public awareness dynamics. To be more accurate in this regard, analysis and evidence proved that abovementioned factors can play an important role in the shaping of Poland position as a swing state in Katowice negotiations. In the author's opinion, the most important factor related to the new function of Poland and had fairly influence on inspiring participants and the progression of the conference was political drivers. Simply put, the current government of Poland although is concerned about the energy security and energy economy, has been trying to take concrete actions and policies for economic transformation domestically. The current political actors in Poland have determined new strategies such as accepting Doha amendment, polish plan for the jungle to change their situation at the international level. The author recommends that Poland need to shape much more transparent climate national targets and policy before implementation which is the trustworthiness of international climate negotiations and protection. Simply put, the agreement stipulates that each country must determine, plan, and regularly report on the contribution that it undertakes to mitigate global warming, Poland can specify the tools or the legal framework under which such monitoring and reporting must be made to show itself as a swing state.

\section{Conflicts of Interest}

The author declares no conflicts of interest regarding the publication of this paper.

\section{References}

[1] Ministry for Europe and Foreign Affairs, France (2017) International Climate Change Negotiations. France Diplomatie. International Climate Negotiations Are Part of a Long Process Which Started with the Founding Conference in Rio in 1992 then the Conference of Parties-COP1-in Berlin in 1995 Deleted from the Text.

[2] Kaya, A. and Steuerle Schofield, L. (2015) The Determinants and Importance of States' Attendance at Conferences of the United Nations Framework Convention on Climate Change (UNFCCC). 9th Annual Conference on the Political Economy of 
International Organizations, 12-14 February 2015, 47.

[3] Kinley, R. (2016) Climate Change after Paris: From Turning Point to the Transformation. Climate Policy, 17, 9-15. https://doi.org/10.1080/14693062.2016.1191009

[4] Kaime, T. (2014) International Climate Change Law and Policy. Routledge Press, New York, 220. https://doi.org/10.4324/9780203796870

[5] Parker, C. and Karlsson, C. (2018) The UN Climate Change Negotiations and the Role of the United States. Environmental Politics Taylor \& Francis, Abingdon-on-Thames, 23.

[6] Chemnick, J. (2018) The U.S. Stands with Russia and Saudi Arabia against Science. https://www.eenews.net/stories/1060109127

[7] Kundzewicz, Z. and Matczak, P. (2012) Climate Change Regional Review: Poland. Wiley Interdisciplinary Reviews: Climate Change, 3, 297-311. https://doi.org/10.1002/wcc.175

[8] Karaczun, Z. (2008) Ewolucja polityki klimatycznej Polski w latach 1988-2008, w Karski, L, GrochowskaI, red. Zmiany Klimatu A Społecze Nstwowarszawa: Beck; 2010 .

[9] Wecker, K. (2018) Poland Clamps down on Environmental Defenders Ahead of UN Climate Talks.

https://www.dw.com/en/poland-clamps-down-on-environmental-defenders-ahead

[10] Priestley, S. (2019) Climate Change Conference (COP24): Katowice, Poland. Briefing Paper, Number CBP8450, 10.

[11] Nero, A. (2019) COP24: UN Climate Change Conference, What's at Stake and What You Need to Know. https://news.un.org/en/story/2018/11/1026851 https://doi.org/10.12968/sece.2019.8.11

[12] IPCC Secretariat (2018) Summary for Policymakers of IPCC Special Report on Global Warming of $1.5^{\circ} \mathrm{C}$ Approved by Governments. http://www.ipcc.ch

[13] UN Environment (2018) Emissions Gap Report 2018. United Nations Environment Program. https://www.unenvironment.org/resources/emissions-gap-report-2018

[14] Benzenberg, J. (2018) $\mathrm{CO}_{2}$ Emissions on the Rise for the First Time in Four Years, UN Agency Warns. UN News, Global Perspective Human Stories. https://news.un.org/en/story/2018/11/1026691

[15] (2018) Greenhouse Gas Levels in the Atmosphere Reach a New Record. https://public.wmo.int/en/media/press-release/greenhouse-gas-levels-atmosphere-r eachnew-record

[16] WMO Greenhouse Gas Bulletin (2018) The State of Greenhouse Gases in the Atmosphere Based on Global Observations through 2017. Japan Meteorological Agency, Tokyo, 8.

[17] WDCGG (World Data Centre for Greenhouse Gases) (2018). https://gaw.kishou.go.jp

[18] Karoly, D. (2017) Scientific Assessment on Ozone Depletion 2018. Australian Research Council's Centre of Excellence for Climate System Science UNSW, Sydney. https://www.climatescience.org.au/content/1158-scientific-assessment-ozone-deplet ion-2018

[19] WMO (2018) Montreal Protocol Assessment Reveals Healing Ozone, Untapped Potential for Climate Action.

https://public.wmo.int/en/media/press-release/montreal-protocol-assessment-revea $\underline{\text { ls }}$

[20] World Meteorological Organization United Nations Environment Programme Na- 
tional Oceanic and Atmospheric Administration National Aeronautics and Space Administration European Commission (2018) Scientific Assessment of Ozone Depletion: 2018. World Meteorological, Geneva, 53.

[21] Purohit, P., Höglund-Isaksson, L. and Wagner, F. (2018) Impacts of the Kigali Amendment to Phasedown Hydrofluorocarbons (HFCs) in Asia. International Institute for Applied Systems Analysis, Laxenburg, 17.

[22] Climate Works Foundation (2018) The State of Play after COP24 and Looking Ahead to 2019. https://www.climateworks.org/blog/state-of-play-after-cop24

[23] Paczosa, A., Mzyk, P. and Szczepański, K. (2017) Seventh National Communication and Third Biennial Report under the United Nations Framework Convention on Climate Change. Ministry of the Environment in Cooperation with the Institute of Environmental Protection, Warsaw. http://www.mos.gov.pl

[24] McLean, E. and Stone, R. (2012) The Kyoto Protocol: Two-Level Bargaining and European Integration. International Studies Quarterly, 56, 99-113. https://doi.org/10.1111/j.1468-2478.2011.00706.x

[25] Skoczkowski, T., Bielecki, S., Węglarz, A., Włodarczak, M. and Gutowski, P. (2018) Impact Assessment of Climate Policy on Poland's Power Sector. Mitigation and Adaptation Strategies for Global Change, 23, 1303-1349.

https://www.ncbi.nlm.nih.gov/pmc/articles/PMC6223833 https://doi.org/10.1007/s11027-018-9786-Z

[26] Dussault, J. (2016) Why Coal-Dependent Poland Signed the Paris Climate Agreement. https://www.csmonitor.com/Environment/2016/1006/Why-coal-dependent

[27] Anderson, K. (2018) Capricious Foes, Big Sister \& High-Carbon Plutocrats: Irreverent Musings from Katowice's COP24. https://kevinanderson.info/blog/author/mcjsska

[28] Appunn, K. (2017) Poland's Katowice COP: Next Coal Country Hosting UN Climate Talks.

https://www.cleanenergywire.org/news/polands-katowice-cop-next-coal

[29] Baran, J., Lewandowski, P., Szpor, A. and Witajewski-Baltvilks, J. (2018) Coal Transition in Poland. IDDRI and Climate Strategies, 36.

[30] Ministry of Foreign Affairs (2018) Together for the Climate-Poland's Initiatives and Actions before COP24. https:/poland.pl/politics/foreign-affairs/together-for-the-climate

[31] Lehr, D. (2018) What's at Stake for COP24? Heinrich Boll Stiftung European Union, Berlin. http://eu.boell.org/en https://doi.org/10.1007/978-1-349-70154-4_7

[32] Arcipowska, A. and Elliott, C. (2018) Here's Poland's Recent History on Climate-and How They Can Steer the Future at COP24.

https://www.wri.org/blog/2018/12/heres-polands-recent-history-climate-and-how-t hey-can-steer-future-cop24

[33] Fontaine, R. and Kliman, D. (2013) India as a "Global Swing State" a New Framework for U.S. Engagement with India.

[34] Schwartzkopff, J. and Schulz, S. (2017) Climate \& Energy Snapshot: Poland the Political Economy of the Low Carbon Transition. E3G, 26. http://www.e3g.org

[35] Lachapelle, E. and Paterson, M. (2013) Drivers of National Climate Policy. Climate Policy, 13, 547-571. https://doi.org/10.1080/14693062.2013.811333

[36] Stefanini, S. (2015) Poland's Duda Bucks EU on Climate. https://www.politico.eu/article/poland-kyoto-protocol-doha-amendment 
[37] WysokieNapiecie.pl. (2015) President Duda-The Little Promise of Change for Energy Policy Lines.

https://wysokienapiecie.pl/777-energy-policy-poland-president-duda-law-and-justi ce

[38] World Economic Forum (2019) What Just Happened? 5 Themes from the COP24 Climate Talks in Poland. World Economic Forum, Cologny.

[39] Riitta Korhola, E. (2014) The Rise and Fall of the Kyoto Protocol: Climate Change as a Political Process. Master, The University of Helsinki, Helsinki.

[40] Goswami, U. (2018) Poland to Formally Adopt Climate Treaty to Reduce Greenhouse Gas Emissions by 2020.

https://economictimes.indiatimes.com/news/politics-and-nation/poland-toformally -adopt-climate-treaty

[41] Reuters (2018) Poland's President Signs Bill on Global Climate Deal Amendment. https://www.reuters.com/article/us-climatechange-accord-eu/polands-president-sig ns-bill-on-global-climate-deal

[42] Borkowski, P. (2018) COP-24 in Katowice Set an Implementation Agenda for the Paris Agreement. European Forestry House, Brussels.

https://eustafor.eu/joint-statement-prior-to-unfcc-cop-24-in-katowice-2

[43] Reuters (2018) Poland Calls for Planting More Forests Worldwide to Improve Carbon Capture.

https://www.reuters.com/article/us-climate-change-poland/poland-calls-for-plantin g-more-forests-worldwide

[44] (2019) Poland and the UK Launch a New Initiative for the Development of Electromobility. http://biznesalert.com/kurtyka-poland-uk-cop24-electromobility

[45] (2019) COP24 a Global Success under the Polish Presidency. https://poland.pl/politics/foreign-affairs/cop24-global-success-under-polish-preside ncy

[46] Ministry of Environment, COP24 (2018) Half of the World Has Supported the Polish Declaration on Electromobility. https://cop24.gov.pl/news/news-details/news/driving-change-together

[47] Garrigou, A.-S. (2018) What Game Is Poland Playing at COP24? https://medium.com/thebeammagazine/what-game-is-poland-playing-at-cop24

[48] COP24 (2018) Just Transition Declaration. United Nations Climate Change Conference, Katowice, 1.

https://cop24.gov.pl/presidency/initiatives/justtransition-declaration

[49] COP24 (2018) The Ministerial Katowice Declaration on Forests for the Climate. Ministry of Environment, Katowice.

[50] (2018) Together for the Climate-Poland's Initiatives and Actions before COP24. https://polska.pl/politics/foreign-affairs/together-for-the-climate-polands-initiatives -and-actions

[51] Chemnick, J. (2018) Poland Celebrates Coal as Talks Start in Mining Capital. E\&E News. https://www.eenews.net/eep

[52] (2019) JSW to Be the First Official Partner of COP24. https://www.jsw.pl/en/media/news/article

[53] (2019) Coal Comfort: COP24 Host Poland Doubles down on Fossil Fuel. https://www.power-technology.com/features/profiling-poland-holding-onto-coal-as -cop-approache

[54] Kukuła, W. (2018) Law and Ambition in Poland's Energy Transition. ClientEarth, 
Warsaw, 11

[55] PKEE (2018) The Polish Power Sector Is Changing. Polish Electricity Association, Warsaw, 1-2. http://www.pkee.pl

[56] Erbach, G. (2015) Negotiating a New UN Climate Agreement Challenges for the Paris Climate Change Conference. European Parliamentary Research Service, 14. http://www.eprs.ep.parl.union.eu

[57] Teffer, P. (2015) Poles Least Worried about Climate Change. Euobserver, Brussels. https://euobserver.com/environment/130980

http://ozone.unep.org/science/assessment/sap 